\title{
Methicillin-Resistant Staphylococcus aureus pada Penderita Dermatitis Atopik dan Sensitivitasnya terhadap Mupirosin Dibandingkan dengan Gentamisin
}

\author{
Keni Istasaputri M., ${ }^{1}$ Endang Sutedja, Oki Suwarsa, ${ }^{2}$ Sunarjati Sudigdoadi ${ }^{2}$ \\ ${ }^{1}$ Sahid Sahirman Memorial Hospital Jakarta Pusat, ${ }^{2}$ Fakultas Kedokteran Universitas Padjadjaran- \\ Rumah Sakit Dr. Hasan Sadikin Bandung
}

\begin{abstract}
Abstrak
Methicillin-resistant Staphylococcus aureus (MRSA) mulai dijumpai pada penderita dermatitis atopik (DA) derajat sedang hingga berat dan bersifat multiresisten terhadap antibiotik topikal. Gentamisin telah digunakan secara luas, sedangkan mupirosin merupakan pilihan utama eradikasi MRSA. Penelitian ini bertujuan untuk mengetahui kolonisasi MRSA pada penderita DA dan sensitivitasnya terhadap mupirosin dibandingkan dengan gentamisin di Poliklinik Departemen Ilmu Kesehatan Kulit dan Kelamin Rumah Sakit Umum Pusat Dr. Hasan Sadikin Bandung. Survei potong lintang analitik dilakukan selama 19 September-31 Oktober 2011 terhadap 22 penderita DA derajat sedang hingga berat sesuai dengan Scoring Atopic Dermatitis objektif dan 22 individu sehat. Seluruh subjek dilakukan pemeriksaan apusan kulit untuk deteksi MRSA dan uji sensitivitas terhadap mupirosin dan gentamisin. Pada kedua kelompok masing-masing didapatkan 10 laki-laki dan 12 perempuan. Pada kelompok penderita DA didapatkan DA derajat sedang (10/22) dan berat (12/22), dengan lesi akut (14/22) dan kronik (8/22). Pertumbuhan $S$. aureus didapatkan pada $17 / 22$ penderita DA dengan sensitivitas terhadap mupirosin 14/17 dan gentamisin 11/17 penderita. Pada individu sehat tidak didapatkan pertumbuhan koloni $S$. aureus. Galur MRSA ditemukan pada 3/17 penderita DA dan dianggap berbeda secara bermakna bila dibandingkan dengan individu sehat $(\mathrm{p}<0,01)$, galur ini bersifat sensitif terhadap mupirosin pada $2 / 3$ penderita dan seluruhnya resisten terhadap gentamisin. Simpulan, kolonisasi MRSA perlu dicurigai pada penderita DA derajat sedang hingga berat, sehingga perlu pengobatan tambahan antibiotik topikal mupirosin. [MKB. 2013;45(1):36-44]
\end{abstract}

Kata kunci: Dermatitis atopik, gentamisin, MRSA, mupirosin

\section{Methicillin-Resistant Staphylococcus aureus in Atopic Dermatitis Patients and Its Sensitivity to Mupirocin Compared to Gentamycin}

\begin{abstract}
Methicillin-resistant Staphylococcus aureus (MRSA) is found in moderate to severe atopic dermatitis (AD) and is multiresistant against topical antibiotic. Gentamycin is widely used while mupirocin is the first line therapy to eliminate MRSA. This research is intended to observe the colonization of MSRA case in AD patients and its sensitivity to mupirocin compared to gentamycin in Dermato-venereology Clinic Dr. Hasan Sadikin General Hospital Bandung. An analytical cross sectional survey was intended from 19th September-31st October 2011 in 22 moderate to severe AD patients based on objective Scoring Atopic Dermatitis and 22 healthy persons. All subjects went through skin-scraping, MSRA was detected and sensitivity test was done for mupirocin and gentamycin. The subjects consisted of 10 boys and 12 girls in both group. Based on severity, 10/22 of $\mathrm{AD}$ subjects were in moderate $\mathrm{AD}$ and 12/22 were severe AD, 14/22 of AD subjects presented with acute lesions and 8/22 subjects had chronic lesions. In the group of AD patients, 17/22 growth of S. aureus were found with sensitivity against mupirocin $14 / 17$ and gentamycin 11/17. In healthy individual group, no S. aureus growth was found. Methicillin-resistant Staphylococcus aureus strain in AD patients was observed on 3/17 patients, and this was declared significantly different compared to healthy individuals $(\mathrm{p}<0.01)$. The isolates in $2 / 3$ patients were sensitive to mupirocin and all patients were resistant to gentamycin. In conclusion, the patients of moderate to severe $\mathrm{AD}$ are prone to MRSA colonization and therefore requires mupirocin topical antibiotic treatment.
\end{abstract} [MKB. 2013;45(1):35-43]

Key words: Atopic dermatitis, gentamycin, MRSA, mupirocin

Korespondensi: Keni Istasaputri M, dr., M.Kes, Sp.KK Sahid Sahirman Memorial Hospital jl. Sudirman No 86 Jakarta Pusat, mobile 08122006132,e-mail keni_istasaputri@yahoo.com 


\section{Pendahuluan}

Dermatitis atopik (DA) merupakan suatu penyakit peradangan kulit yang mempunyai sifat kronik, ${ }^{1}$ hilang timbul,, 2 ditandai dengan ruam kulit yang terasa gatal dan distribusi biasanya pada daerah fleksural serta umumnya mempunyai hubungan dengan penyakit atopik lainnya pada penderita maupun anggota keluarga. ${ }^{2}$ Kolonisasi $S$. aureus ditemukan pada lebih dari 90\% kulit penderita $\mathrm{DA}^{1}$ sebagai akibat gangguan fungsi sawar kulit dan imunitas alamiah, ${ }^{3}$ sedangkan pada individu sehat hanya ditemukan pada $5-25 \%$ populasi. ${ }^{1}$ Bakteri ini dapat mencetuskan DA dan inflamasi kulit dengan menyekresi beberapa toksin yang berperan sebagai superantigen serta mengaktivasi sel T dan makrofag. ${ }^{2}$

Pada tahun 1961 di Eropa, muncul galur $S$. aureus yang membawa sifat resisten terhadap metisilin dan antibiotik dari golongan beta-laktam lain disebut methicillin-resistant Staphylococcus aureus (MRSA), sedangkan galur yang masih bersifat sensitif dinamakan methicillin sensitive Staphylococcus aureus (MSSA). Galur MRSA dapat menyebar dengan cepat, menjadi penyebab sekitar 50\% infeksi nosokomial di rumah sakit serta dikenal sebagai hospital acquired methicillin resistant Staphylococcus aureus (HA-MRSA). Pada tahun 1980 timbul galur community acquired methicillin-resistant Staphylococcus aureus (CAMRSA) dan menyebabkan 30\% infeksi $S$. aureus di masyarakat. ${ }^{4}$

Kolonisasi MRSA pada individu yang sehat dilaporkan sebanyak 5,1\% di Korea Selatan, 4,3\% di Jepang, dan 1,9\% di Taiwan. ${ }^{5}$ Galur MRSA saat ini tidak hanya resisten terhadap metisilin, melainkan memiliki sifat multiresisten terhadap berbagai antibiotik lain yang umum digunakan seperti aminoglikosida, makrolid, kloramfenikol, dan fluorokuinolon, namun istilah MRSA masih digunakan. ${ }^{4}$

Seiring ditemukan CA-MRSA di masyarakat, dapat ditemukan pada lesi kulit penderita DA, ${ }^{5}$ terutama penderita DA dengan derajat sedang sampai berat. ${ }^{6}$ Akiyama dkk. ${ }^{6}$ melaporkan MRSA terdapat pada $31 \%$ penderita DA, sedangkan Schlievert dkk. ${ }^{7}$ menemukan pada $25 \%$ penderita DA. Matiz dkk. ${ }^{8}$ mengemukakan bahwa penderita DA anak terdapat pada $14,1 \%$ kolonisasi MRSA. Chung dkk. ${ }^{5}$ melaporkan MRSA sebanyak 18,4\%.

Pengobatan lini pertama DA dengan emolien dan kortikosteroid topikal. Penanganan penderita DA dengan eksaserbasi, infeksi sekunder, maupun derajat keparahan yang cukup berat, pengobatan antibiotik topikal dipergunakan untuk melawan $S$. aureus sangat penting. Penderita DA derajat sedang sampai berat memperlihatkan perbaikan klinis yang bermakna dengan terapi kombinasi emolien, kortikosteroid topikal, dan antibiotik topikal. ${ }^{3}$ Galur MRSA pada penderita DA akan menyebabkan penatalaksanaan lebih sulit ${ }^{7,8}$ oleh karena bersifat multiresisten terhadap berbagai antibiotik yang biasa digunakan. ${ }^{8}$

Gentamisin telah dipergunakan secara luas dalam bidang dermatologi sejak tahun 1960 untuk penanganan infeksi kulit maupun pengobatan topikal sesudah dilaksanakan tindakan. ${ }^{9}$ Chung dkk. ${ }^{5}$ mengemukakan bahwa pada penderita DA, sensitivitas terhadap gentamisin sebesar 99,7\%, sedangkan pada MRSA sebesar 41,2\%. Mupirosin merupakan pilihan antibiotik utama untuk infeksi MRSA sampai saat ini. Preparat ini paling banyak diteliti sebagai monoterapi eradikasi MRSA di seluruh dunia dan telah banyak digunakan secara luas untuk dekolonisasi MRSA. ${ }^{10}$ Huang dkk. ${ }^{10}$ melaporkan sensitivitas MRSA pada penderita DA terhadap mupirosin masih $100 \%$.

Dermatitis atopik merupakan penyakit kronik yang membutuhkan pemakaian antibiotik topikal dalam waktu lama, sehingga dapat mencetuskan resistensi, karena seiring dengan waktu, S. aureus mempunyai kemampuan untuk mempertahankan serta menyesuaikan diri terhadap lingkungan. ${ }^{10}$ Identifikasi dari kolonisasi MRSA pada penderita DA secara dini dan akurat sangat penting untuk pemilihan pengobatan antibiotik yang sesuai dan pemeliharaan kepekaan jenis antibiotik yang telah ada, selain itu sensitivitas bakteri terhadap berbagai antibiotik juga dapat bervariasi sesuai dengan lingkungan. ${ }^{7}$ Penelitian untuk mengetahui kolonisasi MRSA pada lesi kulit penderita DA dibandingkan dengan kulit individu sehat, serta mengetahui sensitivitas terhadap terapi mupirosin dibandingkan dengan gentamisin belum pernah dilakukan di Indonesia. Mengingat hal tersebut, penulis merasa perlu untuk melakukan penelitian ini untuk memperoleh landasan terapi empiris antibiotik topikal pada penderita DA di Poliklinik Departemen Ilmu Kesehatan Kulit dan Kelamin Rumah Sakit Dr. Hasan Sadikin (RSHS) Bandung.

\section{Metode}

Pada penelitian ini, survei potong lintang analitik dilakukan pada 19 September-31 Oktober 2011 terhadap 22 subjek penderita DA dan 22 individu sehat. Kelompok DA adalah penderita DA yang berkunjung ke Poliklinik Ilmu Kesehatan Kulit dan Kelamin RSHS Bandung dan dipilih secara consecutive sampling sesuai kriteria inklusi lakilaki atau perempuan berusia $\geq 2$ tahun, diagnosis DA sesuai kriteria Hanifin-Rajka, serta termasuk DA dengan derajat sedang dan berat berdasarkan penilaian Scoring Atopic Dermatitis (SCORAD) objektif. Kriteria Hanifin-Rajka harus meliputi 
Tabel 1 Karakteristik Jenis Kelamin, Usia, Pendidikan, dan Pekerjaan pada Penderita DA dan Individu Sehat

\begin{tabular}{lccc}
\hline \multicolumn{1}{c}{ Variabel } & \multicolumn{2}{c}{ Kelompok } & Kemaknaan \\
\cline { 2 - 3 } & $\begin{array}{c}\text { DA } \\
(\mathbf{n}=\mathbf{2 2})\end{array}$ & $\begin{array}{c}\text { Individu Sehat } \\
(\mathbf{n}=\mathbf{2 2})\end{array}$ & \\
\hline Jenis kelamin & & 10 & \\
$\quad$ Laki-laki & 10 & 12 & $\mathrm{p}=1,0$ \\
$\quad$ Perempuan & 12 & & \\
Usia (tahun) & & 9 & $\mathrm{p}=1,0$ \\
$2-6$ & 9 & 6 & \\
$7-12$ & 6 & 7 & \\
$>12$ & 7 & & \\
Pendidikan & & 9 & \\
$\quad$ Belum sekolah & 8 & 7 & \\
SD & 8 & 2 & \\
SLTP & 2 & 2 & \\
SMU & 1 & 2 & \\
$\quad$ Perguruan Tinggi & 3 & & \\
Pekerjaan & & 16 & \\
$\quad$ Tidak bekerja & 17 & 6 & \\
Bekerja & 5 & & \\
\hline
\end{tabular}

*) uji chi-kuadrat

3 dari 4 kriteria mayor dan paling sedikit 3 dari 23 kriteria minor. Penilaian SCORAD objektif dihitung dengan menggunakan rumus $\mathrm{A} / 5+7 \mathrm{~B} / 2$. Dalam hal ini A: persentase luas kelainan kulit sesuai dengan rule of nine, B: penjumlahan 7 tanda khas pada satu daerah ekzem yang representatif yaitu eritema, bengkak, oozing atau krusta, tanda garukan, likenifikasi, kekeringan kulit. Masingmasing tanda dinilai sebagai $0=$ tidak ada keluhan, $1=$ ringan, $2=$ sedang, $3=$ berat, dan jumlah nilai maksimal adalah 18 .

Individu sehat ialah pengantar penderita yang berobat ke Poliklinik Departemen Ilmu Kesehatan Kulit \& Kelamin RSHS Bandung, diambil secara random sampling melalui proses matching sesuai dengan usia serta jenis kelamin penderita DA. Kriteria eksklusi pada kedua kelompok apabila mempergunakan antibiotik topikal atau sistemik dalam 2 (dua) minggu terakhir, pada kelompok penderita DA ditambah dengan lesi DA hanya di daerah intertriginosa karena merupakan daerah predileksi $S$. aureus sebagai flora normal dan menderita infeksi pioderma.

Penelitian ini ialah survei potong lintang yang bersifat analitik. Pada kelompok DA dilakukan apusan dari kerokan kulit lesi pada fleksor lengan bawah atau lesi lain yang bukan terdapat di daerah lipatan. Kulit yang akan diperiksa dibersihkan dahulu dengan kasa natrium klorida $(\mathrm{NaCl}) 0,9 \%$ steril, diletakkan sumuran stainless steel $2 \times 2 \times 2$ $\mathrm{cm}^{3}$, larutan $\mathrm{NaCl} 0,9 \%$ dimasukkan dengan spuit $1 \mathrm{~mL}$, daerah tersebut dikerok perlahan-lahan, setelah itu cairan yang terdapat dalam sumuran diambil kembali menggunakan spuit $1 \mathrm{~mL}$. Pada individu sehat, pengambilan lokasi kerokan kulit disesuaikan dengan lokasi pada penderita DA.

Tabel 2 Pertumbuhan $S$. aureus pada Penderita DA dan Individu Sehat

\begin{tabular}{cccc}
\hline Pertumbuhan & $\begin{array}{c}\text { Penderita DA } \\
\mathbf{n = 2 2}\end{array}$ & $\begin{array}{c}\text { Individu Sehat } \\
\mathbf{n = 2 2}\end{array}$ & Kemaknaan \\
\hline S. aureus $(+)$ & 17 & 0 & $\mathrm{X} 2=24,54$ \\
S. aureus $(-)$ & 5 & 22 & $\mathrm{p}<0,001$ \\
\hline
\end{tabular}




\begin{tabular}{lcc}
$\begin{array}{c}\text { Tabel } 3 \\
\text { Pertumbuhan Galur MRSA pada } \\
\text { Penderita DA Dibandingkan dengan } \\
\text { Individu Sehat }\end{array}$ & $\begin{array}{c}\text { Penderita DA } \\
\mathbf{n = 2 2}\end{array}$ & $\begin{array}{c}\text { Individu Sehat } \\
\mathbf{n = 2 2}\end{array}$ \\
\hline MRSA & 3 & 0 \\
MSSA & 14 & 0 \\
Tidak tumbuh & 5 & 22 \\
\hline
\end{tabular}

Keterangan: MRSA: Methicillin-resistant S. aureus, MSSA: Methicillin-sensitive S. aureus

*) uji chi-kuadrat, kemaknaan X2=7,118, $<<0,01$

Spesimen diinokulasi pada medium mannitol salt agar (MSA) Oxoid TM dan diinkubasi pada suhu $37{ }^{\circ} \mathrm{C}$ selama $18-24$ jam di laboratorium Departemen Mikrobiologi Fakultas Kedokteran Universitas Padjadjaran. Identifikasi S. aureus dilakukan dengan uji tes koagulase metode slide menggunakan kit Staphylase test Oxoid TM. Bila bernilai negatif akan dilakukan konfirmasi dengan tes koagulase metode tabung mempergunakan plasma segar pada suhu inkubasi $37{ }^{\circ} \mathrm{C}$ selama 4 jam. Pada isolat yang teridentifikasi $S$. aureus, kemudian dilanjutkan dengan proses inokulasi pada medium Mueller-Hinton untuk pemeriksaan sensitivitas terhadap antibiotik dengan metode difusi agar, yaitu metode Kirby-Bauer. Dilakukan uji sensitivitas terhadap mupirosin, gentamisin, dan sefoksitin untuk deteksi MRSA. Selain itu dilakukan pemeriksaan sensitivitas terhadap asam fusidat, eritromisin, neomisin, dan klindamisin, kemudian diamati dan juga dihitung lebar zona hambat pertumbuhan bakteri di sekeliling cakram antibiotik.

Analisis statistik dimulai dengan melakukan matching, yaitu penyesuaian jenis kelamin dan usia antara kelompok penderita DA dan individu sehat. Usia merupakan data numerik, sehingga uji kesetaraan yang digunakan adalah uji t bila data berdistribusi normal atau Uji Mann-Whitney bila data tidak berdistribusi normal, sedangkan jenis kelamin adalah data kategorik, sehingga untuk uji kesetaraan proporsi mempergunakan uji chikuadrat. Hasil pengamatan survei potong lintang disusun dalam tabel $2 \times 2$ dan pengukuran besar risiko dihitung besar rasio prevalens dengan $95 \%$ interval kepercayaan.

Analisis statistik untuk melihat proporsi DA dan kontrol dipergunakan uji kesamaan proporsi mempergunakan statistik uji chi-kuadrat dan Uji Exact Fisher. Analisis data dilakukan dengan menggunakan program SPSS for Windows versi 13.0 pada derajat kepercayaan $95 \%$ dengan nilai $\mathrm{p}<0,05$.

Aspek etik penelitian ini meliputi pemberian informasi lengkap kepada subjek penelitian yang apabila sudah menyetujui akan menandatangani persetujuan (informed consent). Setiap informasi dan data penelitian diperlakukan secara rahasia. Perlakuan yang sama yaitu pemerikasan apusan kerokan kulit dilakukan pada kelompok penderita DA atau individu sehat yang memenuhi kriteria inklusi. Tidak ada risiko atau efek samping yang akan dirasakan penderita oleh karena pemeriksaan dilakukan hanya pada permukaan kulit dan tidak ada perlukaan tertentu. Manfaat bagi kelompok penderita DA, yaitu dengan ditemukannya MRSA melalui metode pemeriksaan yang sensitif, maka subjek dapat memperoleh pengobatan antibiotik paling tepat dengan seluruh biaya pengobatan akan ditanggung oleh peneliti. Kelompok individu sehat tidak memperoleh manfaat secara langsung, namun dapat turut serta mengembangkan ilmu pengetahuan dan akan mendapatkan kompensasi dari peneliti.

\section{Hasil}

Karakteristik jenis kelamin subjek baik pada kelompok penderita DA maupun individu sehat adalah sama, yaitu terdiri dari 10 laki-laki dan 12 perempuan dengan kelompok usia terbanyak 2-6 tahun $(9 / 22$ penderita).

Diagnosis DA ditentukan berdasarkan kriteria Hanifin-Rajka. Pada kriteria mayor, sebanyak 21 dari 22 penderita mengalami gatal, perjalanan penyakit kronik dan atau rekuren, serta terdapat riwayat penyakit atopik pada penderita dan atau keluarga. Pada kriteria minor, semua penderita mengeluh serosis dan sebagian besar mengeluh gatal bila berkeringat (18/22 penderita).

Penilaian derajat DA ditentukan berdasarkan penelitian SCORAD objektif yaitu nilai $<15$ adalah DA derajat ringan, nilai 15-40 adalah DA dengan derajat sedang, sedangkan nilai 40-83 adalah DA derajat berat. ${ }^{11}$ Pada penelitian ini, dipilih subjek penelitian dengan kriteria inklusi DA derajat sedang dan berat yang sesuai penilaian SCORAD objektif. Keseluruhan penderita DA memiliki nilai SCORAD objektif rata-rata 39,41; median 41,75 ; dengan nilai terkecil 16 , dan nilai terbesar 73 , sehingga didapatkan $10 / 22$ penderita mengalami DA dengan derajat sedang dan 12/22 penderita mengalami DA derajat berat.

Pada semua penderita ditemukan efloresensi berupa makula eritema dan skuama, kemudian ditemukan papula eritema pada $21 / 22$ penderita, likenifikasi sebanyak $11 / 22$ penderita, erosi dan krusta masing-masing pada 10/22 penderita. Lesi akut ditemukan pada $14 / 17$ penderita dan lesi kronik pada sebanyak 8/17 penderita.

Hasil pemeriksaan mikrobiologis didapatkan 
Keni Istasaputri: Methicillin-resistant Staphylococcus aureus pada Penderita Dermatitis Atopik dan Sensitivitasnya

Tabel 4 Sensitivitas $S$. aureus terhadap Antibiotik Topikal pada Penderita DA

\begin{tabular}{lccccccc}
\hline Kategori & $\mathbf{M}$ & $\mathbf{G}$ & $\mathbf{E}$ & $\mathbf{A F}$ & $\mathbf{K}$ & $\mathbf{T}$ & $\mathbf{N}$ \\
\cline { 2 - 8 } & $\mathbf{n = 1 7}$ & $\mathbf{n = 1 7}$ & $\mathbf{n = 1 7}$ & $\mathbf{n = 1 7}$ & $\mathbf{n = 1 7}$ & $\mathbf{n = 1 7}$ & $\mathbf{n = 1 7}$ \\
\hline Sensitif & 14 & 11 & 13 & 14 & 13 & 11 & 11 \\
Intermediate & 3 & 0 & 2 & 0 & 0 & 0 & 0 \\
Resisten & 0 & 6 & 2 & 3 & 4 & 6 & 6 \\
\hline
\end{tabular}

Keterangan: $\mathrm{M}=$ mupirosin, $\mathrm{G}=$ gentamisin, $\mathrm{E}=$ eritromisin, $\mathrm{AF}=$ asam fusidat, $\mathrm{K}=$ klindamisin, $\mathrm{T}=$ tetrasiklin, $\mathrm{N}=$ neomisin

pertumbuhan $S$. aureus pada kelompok penderita DA, baik galur MRSA maupun MSSA, yaitu sebanyak 17 dari 22 penderita, sedangkan pada seluruh kelompok individu sehat tidak didapatkan pertumbuhan bakteri tersebut. Dari 17 penderita DA terdapat pertumbuhan galur MRSA pada 3 dari 17 penderita. Secara keseluruhan sensitivitas S. aureus pada penderita DA masih baik terhadap berbagai antibiotik topikal yang biasa digunakan. Pertumbuhan galur MRSA hanya didapatkan pada 3 dari 17 penderita DA serta dianggap berbeda secara bermakna dengan kelompok individu yang sehat karena memberikan nilai $\mathrm{p}<0,01$.

\section{Pembahasan}

Pada kedua kelompok didapatkan 12 perempuan dan 10 laki-laki karena subjek pada penderita DA ditentukan berdasarkan urutan antrian, sedangkan pada kelompok individu sehat disesuaikan dengan proses matching supaya dapat dianggap homogen sehingga layak diperbandingkan.

Dermatitis atopik lebih sering terjadi pada subjek laki-laki dibandingkan dengan perempuan dengan rasio yang hampir sama yaitu 1,3:1,2. Jenis kelamin pada penelitian ini sesuai dengan penelitian yang dilakukan Sugarman dkk., ${ }^{11}$ yaitu perempuan lebih banyak daripada laki-laki.

Berdasarkan karakteristik usia, sebagian besar subjek pada kedua kelompok berusia 2-6 tahun yaitu sebanyak $9 / 22$ penderita karena pemilihan kriteria inklusi penderita DA adalah DA sedang sampai dengan berat. Pada anak berusia 2-6 tahun yang menderita DA cenderung memiliki derajat keparahan yang berat dengan lesi kulit yang luas, sedangkan derajat keparahan DA akan berkurang sesuai dengan perkembangan usia anak.

Hal ini sesuai dengan onset penyakit DA yaitu sebanyak 50\% kasus terjadi pada usia dua tahun, $60 \%$ pada usia lebih dari enam tahun, dan hanya pada sebagian kecil penderita terjadi setelah usia 20 tahun. ${ }^{2}$ Karakteristik usia pada penelitian ini sesuai dengan Chung dkk. ${ }^{7}$ yang memiliki subjek penelitian penderita DA derajat sedang hingga berat dan didapatkan usia 2-6 tahun 58,5\% dan lebih dari 7 tahun $41,5 \%$.

Kriteria Hanifin-Rajka dipergunakan untuk mendiagnosis DA. Pada kriteria mayor, 21 dari 22 orang penderita mengalami keluhan gatal, perjalanan penyakit yang kronik dan atau rekuren, dan terdapat riwayat atopik pada penderita atau keluarga, dan 19 dari 22 orang penderita memiliki ruam kulit berupa likenifikasi di daerah fleksor pada anak dan dewasa, atau berupa ruam kulit di daerah wajah dan atau ekstensor pada bayi. Pada kriteria minor, semua penderita memiliki keluhan serosis, dan sebagian besar mempunyai keluhan gatal bila berkeringat sebanyak $18 / 22$ penderita, perjalanan penyakit yang dipengaruhi lingkungan atau emosional sebanyak $16 / 22$ penderita, serta kecenderungan dermatitis pada tangan dan kaki yang tidak spesifik sebanyak $15 / 22$ penderita.

Hasil ini sesuai dengan Bohme dkk. ${ }^{12}$ yang melakukan penelitian deskriptif mengenai kriteria Hanifin Rajka pada penderita DA, dan didapatkan sebanyak 92\% penderita memiliki 3 dari 4 kriteria mayor, sedangkan pada kriteria minor didapatkan

Tabel 5 Sensitivitas MRSA terhadap Antibiotik Topikal pada Penderita DA

\begin{tabular}{lccccccc}
\hline Kategori & $\mathbf{M}$ & $\mathbf{G}$ & $\mathbf{E}$ & $\mathbf{A F}$ & $\mathbf{K}$ & $\mathbf{T}$ & $\mathbf{N}$ \\
\hline & $\mathbf{n = 3}$ & $\mathbf{n}=\mathbf{3}$ & $\mathbf{n = 3}$ & $\mathbf{n = 3}$ & $\mathbf{n = 3}$ & $\mathbf{n = 3}$ & $\mathbf{n = 3}$ \\
\hline Sensitif & 2 & 0 & 0 & 0 & 1 & 0 & 0 \\
Intermediate & 1 & 0 & 1 & 1 & 0 & 0 & 0 \\
Resisten & 0 & 3 & 2 & 2 & 2 & 3 & 3 \\
\hline
\end{tabular}

Keterangan: $\mathrm{M}=$ =mupirosin, $\mathrm{G}=$ gentamisin, $\mathrm{E}=$ eritromisin, $\mathrm{AF}=$ asam fusidat, $\mathrm{K}=$ =klindamisin, $\mathrm{T}=$ tetrasiklin, $\mathrm{N}=$ neomisin 


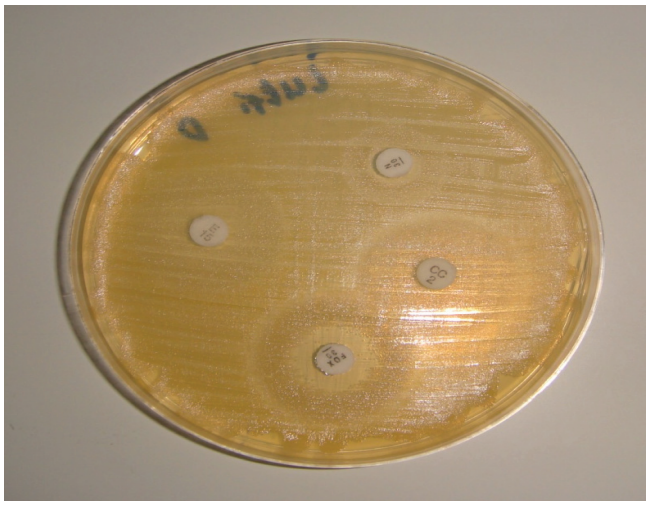

Gambar Hasil Uji Kepekaan Galur MRSA:
Tampak Bersifat Multiresisten
terhadap Berbagai Antibiotik Topikal

serosis $100 \%$, perjalanan penyakit dipengaruhi lingkungan $87 \%$, gatal jika berkeringat $34 \%$, dan dermatitis pada tangan atau kaki $28 \%$.

Penilaian derajat DA ditentukan berdasarkan penelitian SCORAD objektif, yaitu bila nilai $<15$ adalah DA dengan derajat ringan, nilai $15-40$ adalah DA derajat sedang, sedangkan nilai 40-83 adalah DA derajat berat. ${ }^{11}$ Pada penelitian ini dipilih subjek dengan kriteria inklusi DA derajat sedang dan berat yang sesuai dengan penilaian SCORAD objektif. Keseluruhan penderita DA memiliki nilai SCORAD objektif rata-rata 39,41; median 41,75 ; dengan nilai terkecil 16 , dan nilai terbesar 73 , sehingga didapatkan 10/22 penderita mengalami DA derajat sedang dan 12/22 penderita mengalami DA derajat berat.

Hasil penelitian ini sesuai dengan penelitian yang dilakukan oleh Khobragade dkk., ${ }^{13}$ yaitu memiliki subjek penelitian penderita DA derajat sedang sampai berat berdasarkan pada penilaian SCORAD objektif dan didapatkan 55,7\% DA derajat sedang dan $44,3 \%$ DA derajat berat.

Pada semua penderita ditemukan efloresensi berupa makula eritema dan skuama, kemudian ditemukan papula eritema pada $21 / 22$ penderita, erosi dan krusta masing-masing pada sebanyak 10/22 penderita, dan likenifikasi sebanyak $11 / 22$ penderita. Lesi akut ditemukan pada 14 dari 22 penderita dan lesi kronik sebanyak 8/22 penderita.

Pada penderita DA dapat ditemukan baik lesi akut maupun kronik secara bersamaan. Lesi akut sering ditemukan pada bayi dan anak, ditandai baik makula dan papula eritema maupun vesikel yang sangat gatal, apabila bertambah parah dapat disertai erosi dan ekskoriasi dengan eksudat serosa. ${ }^{1,2}$ Lesi kronik sering ditemukan pada usia dewasa, ditandai dengan papula atau plak yang kering dan juga menebal, serta likenifikasi. ${ }^{1}$ Hasil karakteristik keadaan lesi kulit penderita DA pada penelitian ini sesuai dengan penelitian AlSaimary dkk. ${ }^{14}$, yaitu ditemukan $65 \%$ lesi akut dan $35 \%$ lesi kronik.

Hasil pemeriksaan mikrobiologis didapatkan pertumbuhan $S$. aureus pada kelompok penderita DA, baik galur MRSA maupun MSSA, terdapat sebanyak 17 dari 22 penderita, sedangkan pada semua kelompok individu sehat tidak didapatkan pertumbuhan bakteri tersebut. Staphylococcus aureus ditemukan pada lebih dari $90 \%$ penderita DA. ${ }^{1}$ Bakteri ini merupakan flora normal pada kulit dan mukosa individu sehat, ${ }^{4}$ namun bukan flora normal yang utama, yaitu hanya 5-30\%. ${ }^{1}$ Pada medium MSA, pertumbuhan dari S. aureus memberikan gambaran koloni kuning dengan halo kuning di sekelilingnya serta dikonfirmasi dengan pelaksanaan tes koagulase. ${ }^{15}$ Hasil ini sesuai dengan Pezesk dkk. ${ }^{16}$ yang menemukan kolonisasi S. aureus ditemukan pada 95\% lesi DA sedangkan pada individu sehat sebesar 7,5\%.

Sebagian besar penderita DA mempunyai jumlah kolonisasi yang banyak yaitu $>105 \mathrm{CFU}$ sebanyak 13 dari 22 penderita, sedangkan koloni jumlah sedikit sebanyak 5 dari 22 penderita dan jumlah sedang sebanyak $4 / 22$ penderita. Hal ini disebabkan pemilihan subjek penelitian penderita DA derajat sedang sampai dengan berat sehingga cenderung memiliki jumlah kolonisasi $S$. aureus yang banyak. Hill dkk. ${ }^{17}$ mengemukakan bahwa jumlah kolonisasi $S$. aureus umumnya berbanding langsung dengan derajat keparahan DA. Pezesk dkk. ${ }^{16}$ mengemukakan bahwa seluruh penderita DA derajat berat mempunyai kolonisasi bakteri tersebut, sedangkan pada derajat sedang hanya terdapat sebanyak $30 \%$.

Pertumbuhan $S$. aureus tidak didapatkan pada kulit seluruh individu sehat, keadaan ini mungkin disebabkan bakteri ini bukan merupakan flora normal utama. Pengambilan kerokan kulit juga disesuaikan dengan lokasi pengambilan sampel pada penderita DA atau terutama diambil dari daerah fleksor lengan bawah, padahal $S$. aureus umumnya merupakan flora normal pada cuping hidung, ketiak, tangan, dan daerah intertriginosa sehingga pengambilan bahan untuk pemeriksaan seharusnya diambil dari lokasi tersebut. Hasil pemeriksaan kultur dari kerokan kulit kelompok individu sehat didapatkan pertumbuhan bakteri yang positif pada sebanyak 9 dari 22 individu sehat, yaitu berupa koloni tidak berwarna dan warna merah muda yang diduga $S$. epidermidis, serta warna putih, kuning, dan jingga yang diduga Micrococcus spp. ${ }^{15}$

Pada penelitian ini, dari 17 orang penderita DA ternyata yang memperlihatkan pertumbuhan galur MRSA terdapat pada 3 (tiga) penderita. Hasil ini sesuai dengan penelitian Chung dkk. ${ }^{7}$ 
yang menemukan bahwa $S$. aureus didapatkan pada $75,4 \%$ penderita DA dan $18,4 \%$ di antaranya adalah MRSA. Spergel ${ }^{18}$ juga mengemukakan bahwa $80 \%$ penderita DA mempunyai kolonisasi $S$. aureus dan MRSA terdapat sebanyak $16 \%$. Lo dkk. ${ }^{19}$ meneliti kolonisasi MRSA pada anak sehat dan didapatkan kolonisasi MRSA 7,4\%; 17,7\% MSSA; dan $74,9 \%$ tidak terdapat pertumbuhan bakteri.

Staphylococcus aureus maupun MRSA pada penderita DA merupakan suatu keadaan kolonisasi diakibatkan sawar kulit penderita DA yang tidak intak. ${ }^{3}$ Kolonisasi yaitu ditemukan keberadaan dan multiplikasi bakteri pada permukaan tubuh tanpa menyebabkan penyakit. ${ }^{3,4}$ Berbeda halnya dengan istilah karier, yaitu suatu keadaan infeksi asimtomatik pada penderita sehingga penderita tersebut mampu membawa dan juga menyebarkan bakteri tersebut sehingga menimbulkan penyakit infeksi pada individu lainnya. Seseorang dapat bertindak sebagai karier $S$. aureus secara persisten maupun intermiten, selain itu keadaan karier juga cenderung mengalami autoinfeksi $S$. aureus. ${ }^{4}$

Kolonisasi bakteri $S$. aureus pada penderita DA dapat menyebabkan penderita menjadi rentan untuk eksaserbasi, sedangkan kolonisasi MRSA akan menyebabkan penderita mempunyai faktor predisposisi infeksi kulit yang berat. ${ }^{5}$ Pengobatan lini pertama DA yaitu penggunaan emolien dan kortikosteroid topikal. ${ }^{3}$ Terapi tambahan berupa antibiotik topikal dianjurkan untuk penderita DA derajat sedang sampai berat untuk mengurangi jumlah kolonisasi dan menekan produksi toksin atau superantigen yang dihasilkan oleh bakteri tersebut. ${ }^{3,10}$

Pengobatan kombinasi kortikosteroid dengan antibiotik topikal akan mempercepat perbaikan klinis penderita DA dan pemakaian jangka pendek kurang dari 2 minggu tidak akan menimbulkan resistensi. ${ }^{21}$ Gentamisin juga dapat dipergunakan untuk penanganan galur $S$. aureus yang tidak membawa sifat multiresisten terhadap antibiotik. Preparat ini telah sering digunakan dalam bidang dermatologi sejak tahun 1960 karena memiliki spektrum luas dan digunakan untuk penanganan infeksi kulit maupun untuk pengobatan topikal setelah pelaksanaan tindakan sehingga dilaporkan mengalami resistensi. ${ }^{9}$ Mupirosin dapat dipilih pada penanganan kolonisasi MRSA. Preparat ini paling banyak dipelajari sebagai monoterapi untuk eradikasi MRSA di seluruh dunia dan telah digunakan secara luas untuk dekolonisasi karier MRSA. ${ }^{4}$

Pada penelitian ini didapatkan sensitivitas $S$. aureus pada 17 penderita DA masih baik terhadap berbagai antibiotik topikal yang biasa digunakan, yaitu bersifat sensitif terhadap mupirosin 14/17 penderita, sedangkan terhadap gentamisin 11/17 penderita, namun berdasarkan analisis statistik hasil ini dinyatakan tidak berbeda secara bermakna $(p=0,210)$. Uji sensitivitas terhadap antibiotik topikal lainnya didapatkan sensitif terhadap asam fusidat pada 14/17 penderita, eritromisin 13/17 penderita, klindamisin 13/17 penderita, neomisin 11/17 penderita, dan tetrasiklin 11/17 penderita.

Huang dkk. ${ }^{10}$ telah melaporkan sensitivitas S. aureus terhadap antibiotik mupirosin sebesar $100 \%$. Al-Saimary dkk. ${ }^{14}$ membuktikan bahwa $S$. aureus pada penderita DA itu bersifat sensitif terhadap gentamisin sebesar $73,4 \%$; eritromisin $17,9 \%$; tetrasiklin 49,1\%; dan klindamisin 53,7\%. Chung dkk. ${ }^{7}$ mendapatkan sensitivitas penderita DA terhadap antibiotik gentamisin, eritromisin, klindamisin, serta asam fusidat pada kolonisasi S. aureus masing-masing sebesar $99,7 \% ; 59,4 \%$; $95,9 \%$; dan $55,1 \%$. Selain itu, tidak ditemukan data sensitivitas neomisin pada penderita DA.

Munculnya galur MRSA pada penderita DA menyebabkan kesulitan pemilihan terapi karena MRSA bersifat multiresisten terhadap berbagai antibiotik dan hal ini telah diketahui secara umum. ${ }^{5}$ Pada penelitian ini, pertumbuhan galur MRSA hanya didapatkan pada sebanyak 3 penderita DA dan dianggap berbeda secara bermakna dengan kelompok individu sehat karena hasil analisis uji chi-kuadrat memberikan nilai $\mathrm{p}<0,01$.

Galur MRSA yang sensitif terhadap mupirosin ditemukan pada 2 dari 3 penderita dan seluruhnya bersifat resisten terhadap gentamisin. Galur ini jugabersifat sensitifterhadap klindamisin pada $1 / 3$ penderita, intermediate terhadap mupirosin, asam fusidat, dan eritromisin pada $1 / 3$ penderita. Galur MRSA resisten terhadap tetrasiklin dan neomisin pada semua penderita, sedangkan terhadap asam fusidat, eritromisin, dan klindamisin hanya pada $2 / 3$ penderita.

Huang dkk..$^{10}$ melaporkan sensitivitas MRSA terhadap mupirosin pada penderita DA sebesar $100 \%$, sedangkan Marais $\mathrm{dkk} .{ }^{20}$ mengemukakan bahwa MRSA bersifat sensitif terhadap mupirosin hanya $96,4 \%$; gentamisin $34,3 \%$; asam fusidat $100 \%$; eritromisin $21,4 \%$; tetrasiklin $42,8 \%$; serta klindamisin $65 \%$. Chung dkk. ${ }^{5}$ mengemukakan pada penderita DA, sensitivitas MRSA terhadap gentamisin, eritromisin, klindamisin, dan asam fusidat menurun menjadi sebesar $41,2 \% ; 17,6 \%$; $58,8 \%$; dan $88,2 \%$.

Pola sensitivitas MRSA terhadap berbagai antibiotik di daerah tertentu sangat penting untuk diketahui sehingga dapat dipergunakan sebagai landasan dalam pemilihan pengobatan antibiotik empiris. ${ }^{20}$ Resistensi MRSA terhadap antibiotik disebabkan oleh karena bakteri ini memproduksi suatu protein mutan penicillin binding protein- $2 a$ (PBP-2a) yang merupakan suatu kelompok enzim pada membran sel yang dapat mengkatalisis reaksi 
transpeptidasi pada pembentukan cross-linkage rantai peptidoglikan. Protein mutan ini disandi gen mecA yang terletak pada mobile genetic element dan disebut sebagai Staphylococcal chromosome cassette mec (SCCmec). Pemeriksaan polymerase chain reaction (PCR) memperlihatkan galur $\mathrm{HA}-$ MRSA memiliki SCCmecII dengan ukuran lebih besar dan berhubungan dengan banyaknya insersi deoxyribonucleic acid (DNA) sehingga bersifat multiresisten terhadap berbagai antibiotik yang biasa dipergunakan seperti golongan beta-laktam, aminoglikosida, fluorokuinolon, makrolid, serta kloramfenikol. Pada galur CA-MRSAmempunyai SCCmecIV dengan ukuran lebih kecil sehingga hanya menyandi sifat resisten terhadap antibiotik golongan penisilin dan makrolid. ${ }^{4}$

Deteksi MRSA pada penelitian ini hanya menggunakan cakram sefoksitin dan pemeriksaan ini memiliki sensitivitas $100 \%$ serta spesifisitas $100 \%$ untuk deteksi gen $m e c A$, namun tidak dapat menggambarkan SCCmec isolat MRSA sehingga tidak dapat membedakan galur HA-MRSA atau CA-MRSA.

Simpulan, kolonisasi MRSA yang terdapat pada lesi kulit penderita DA derajat sedang hingga berat didapatkan hasil lebih tinggi dibandingkan dengan kulit individu sehat dan MRSA bersifat lebih sensitif terhadap mupirosin dibandingkan dengan gentamisin di Poliklinik Departemen IK Kulit dan Kelamin RSHS Bandung. Penderita DA derajat sedang hingga berat memiliki risiko lebih tinggi untuk memiliki kolonisasi MRSA. Kolonisasi MRSA pada tiga orang penderita DA bersifat sensitif terhadap mupirosin dan seluruh kolonisasi resisten terhadap gentamisin, sehingga sebaiknya perlu diberikan pengobatan tambahan antibiotik topikal mupirosin. Penderita yang tidak responsif dengan pemberian antibiotik topikal sesuai dengan terapi empiris dalam jangka waktu dua minggu, sebaiknya dilakukan pemeriksaan apusan kerokan kulit untuk pemeriksaan kultur dan sensitivitas terhadap antibiotik.

Penelitian dengan jumlah sampel lebih banyak dan berkala perlu dilakukan sehingga diharapkan kolonisasi MRSA dapat ditemukan lebih banyak guna memperoleh landasan terapi empiris untuk kolonisasi MRSA pada penderita DA.

\section{Daftar Pustaka}

1. Leung DYM, Eichenfield LF, Boguniewicz M. Atopic dermatitis (atopic eczema). Dalam: Wolff K, Goldsmith LA, Katz SI, Gilchrest BA, Paller AS, Leffel DA, penyunting. Fitzpatrick's dermatology in general medicine. Edisi ke-7. New York: McGraw-Hill; 2008. hlm.146-57.
2. Friedmann PS, Ardern-Jones MR, Holden CA. Atopic dermatitis. Dalam: Burns T, Breathnach S, Cox N, Griffiths C, penyunting. Rook's textbook of dermatology. Edisi ke-8. New Jersey: Willey-Blackwell Ltd; 2010. hlm. 1-33.

3. Maintz L, Novak N. Getting more and more complex: the pathophysiology of atopic eczema. Eur J Dermatol. 2007;17(4):267-83.

4. Hartstein AI, Sebastian TJ, Strausbaugh LJ. Methicillin-resistant Staphylococcus aureus. Dalam: Mayhall CG, penyunting. Hospital epidemiology and infection control. Edisi ke-3. Philadelphia: Lippincott Williams \& Wilkins; 2004. hlm. 1593-608.

5. Chung HJ, Jeon HS, Sung H, Kim MN, Hong SJ. Epidemiological characteristics of methicillin-resistant Staphylococcus aureus isolates from children with eczematous atopic dermatitis lesions. J Clin Microbiol. 2008;46(3):991-5.

6. Akiyama H, Yamasaki O, Tada J, Arata J. Adherence characteristics and susceptibility to antimicrobial agents of Staphylococcus aureus strains and isolated from skin infections and atopic dermatitis. J Dermatol Sci. 2000;23(3):155-60.

7. Schlievert PM, Strandberg KL, Lin YC, Peterson ML, Leung DY. Secreted virulence factor comparison between methicillinresistant Staphylococcus aureus dan methicillin-sensitive and its relevance to atopic dermatitis. J Allergy Clin Immunol. 2010;125(1):39-49.

8. Matiz C, Tom WL, Eichenfield LF, Pong A, Friedlander SF. Children with atopic dermatitis appear less likely to be infected with community acquired and methicillinresistant Staphylococcus aureus infection: the San Diego experience. Pediatr Dermatol. 2011;28(1):6-11.

9. Schwartz RA, Al-Mutairi N. Topical antibiotics in dermatology: an update. GJDV. 2010;17(1):1-19.

10. Huang JT, Abrams M, Tlougan B, Rademaker A, Paller AS. Treatment of Staphylococcus aureus colonization in atopic dermatitis decreases disease severity. Pediatrics. 2009;123(5):e808-14.

11. Sugarman JL, Fluhr JW, Fowler AJ, Bruckner T, Diepgen TN, Williams ML. The objective severity assessment of atopic dermatitis score:an objective measure using permeability barrier function and stratum corneum hydration with computer assisted estimates for extent of disease. Arch Dermatol. 2003;139(11):1417-22.

12. Bohme M, Svensson A, Kull I, Wahlgreen 
CF. Hanifin's and Rajka's minor criteria for atopic dermatitis: which do 2-years-olds exhibit? J Am Acad Dermatol. 2004;43(5 Pt 1):785-92.

13. Khobragade KJ. Efficacy and safety of combination ointment "fluticasone propionate $0.005 \%$ plus mupirocin $2.0 \% "$ for the treatment of atopic dermatitis with clinical suspicion of secondary bacterial infection: an open label uncontrolled study. Indian $\mathbf{J}$ Dermatol Venereol Leprol. 2005;71(2):91-5.

14. Al-saimaru IE, Bakr SS, Al-Hamdi KE. Staphylococcus aureus as a causative agent of atopic dermatitis/eczema syndrome (ADES) and its theraupetic implications. Int J Dermatol. 2006;4(2):123-8.

15. Forbes BA. Bailey and Scott's diagnostic microbiology. Edisi ke-11. St Louis-Missouri: Mosby-Inc; 2003. hlm. 707-23.

16. Pezesk FZ, Miri S, Ghasemi R, Farid R, Ghenaat J. Skin colonization with
Staphylococcus aureus in patients with atopic dermatitis. Int J Dermatol. 2007;5(1):150-9.

17. Hill SE, Yung A, Rademaker M. Prevalence of Staphylococcus aureus and antibiotic resistance in children with atopic dermatitis: a New Zealand experience. Australiasian J Dermatol. 2011;52(1):27-31.

18. Spergel JM. Methicillin-resistant Staphylococcus aureus colonization in children with atopic dermatitis. Pediatrics. 2009; 124S:130.

19. Lo WT, Lin WJ, Tseng MH, Wang SR, Wang CC. Dissemination of methicillin-resistant Staphylococcus aureus among healthy children in Northern Taiwan. J Med Sci. 2010;30(2):47-53.

20. Marais E, Aithma N, Perovic O, Oosthuysen WF, Musenge E, Duse AG. Antimicrobial susceptibility of methicillin-resistant Staphylococcus aureus isolates from South Africa. S Afr Med J. 2009;99(3):170-3. 